\title{
Effect of Ascorbic Acid Supplementation Methods on Some Productive and Physiological Performances of Laying Hens
}

\author{
Abdalla M. Abdalla ${ }^{1}$, Erneo B. Ochi ${ }^{2}$ \\ ${ }^{I}$ Department of Breeding and Reproduction Biotechnology, College of Animal Production, University of Bahri, \\ Khartoum North, Sudan \\ ${ }^{2}$ Department of Animal Production, College of Natural Resources and Environmental Studies, University of \\ Juba, Juba, South Sudan.
}

*Corresponding Author: Erneo B. Ochi, Department of Animal Production, College of Natural Resources and Environmental Studies, University of Juba, Juba, South Sudan

\begin{abstract}
A 6-week study was conducted to evaluate the effect of three different methods for ascorbic acid (AA) supplementation on some productive and physiological performances of laying hens. Eighty (80), 4month old Bovan pullets of similar body weights were divided into four experimental treatments $(A, B, C$, and $D)$ of four replicates each in a completely randomized block design. Each replicate was subdivided into five hens. Control treatment A contained no AA in both basal diet and drinking water. Treatment B contained $1,000 \mathrm{mg} \mathrm{AA} / \mathrm{kg}$ diet- basal diet and AA-free drinking water. Treatment C contained $500 \mathrm{mg} \mathrm{AA/} \mathrm{kg} \mathrm{diet-}$ basal diet and $500 \mathrm{mg} A A$ - drinking water. Treatment $D$ contained AA-free basal diet and 1,000 $\mathrm{mg} A A$ drinking water. Body weight gain, feed conversion ratio (FCR), body temperature, total and differential leucocyte counts and heterophils to lymphocytes ratio were investigated. Data were analyzed using analysis of variance (ANOVA) and Duncan's Multiple Range Test. Ascorbic acid supplementation had a significant $(p<0.05)$ positive effect on the body weight gain, body temperature and total leucocytes count compared to a significant $(p<0.05)$ negative effect on FCR. No significant treatment effect shown from supplementation of $A A$ on heterophils to lymphocytes ratio. Ascorbic acid supplementation with feed could improve bird performances under optimum environmental or reduced body temperature.
\end{abstract}

Keywords: Poultry; Heat stress; Ascorbic acid; Productive performance; Physiological performance.

\section{INTRODUCTION}

Ascorbic acid (AA) or commonly known as Vitamin $\mathrm{C}$ is principally synthesized in the chicken' kidneys (Melvin, 1977) compared to chemically isolated commercial AA (L-AA) which is a white crystalline powder active in water (Abidin and Khatoon, 2013). As such no recommended AA requirements established for poultry regimen (NRC, 1994). Nevertheless, AA supplementation is imperative for the formation and maintenance of intracellular materials in the bones and soft tissues, and it serves as a catalyst in healing processes (John and John, 1975).

High environmental temperature is challenging to laying hens during hot summer months (Ciftci et al., 2005) and the ideal temperature for such layers was reported to be $20^{\circ} \mathrm{C}$ (North and Bell, 1990). Heat stress in laying hens begins when the ambient temperature reaches $25{ }^{\circ} \mathrm{C}$ and exceeds $30{ }^{\circ} \mathrm{C}$ (Ciftci et al., 2005). Such high temperatures impose severe stress in layer birds (Ajakayie et al., 2011), leading to oxidative stress associated with increased oxidative damage and lowered plasma concentrations of antioxidant vitamins (Sahin et al., 2009) including vitamins: C and E (Sahin et al., 2002; Ahamlu et al., 2016). Additionally, water soluble vitamins were found to have immunomodulatory effects on heat stressed broiler chickens (Bashir et al., 1998). The heat stressed birds are observed to spend less time for feeding, but more time for drinking water and resting, let alone a panting phenomenon which is manifested by elevated wings (Mack, 2013).

Evidence has shown that heat stress reduces live weight gain, feed intake, eggs quality production, and increases mortality (Bollinger-Lee et al., 1999). Moreover, heat stress decreases nutrients utilization and feed efficiency, leading to economic losses in layer poultry (Mashaly et al., 2004; Sahin et al., 2009). Furthermore, heat stress leads to a decrease in a total leucocytes count (Gross et al., 1980) and an increase in the bird's heterophils to lymphocytes ratio (Sigel, 1995; Post et al., 
Effect of Ascorbic Acid Supplementation Methods on Some Productive and Physiological Performances of Laying Hens

2003). As such nutritional intervention seemed to be imperative for sustainability of broilers rearing during heat stress (Gous and Morris, 2005).

It is reported that AA supplementation could improve poultry performance when exposed to heat stress (Mack, 2013; Jadhav et al., 2013). The demand for AA during heat stress increases but its synthesis becomes insufficient to meet the bird's requirement (Abidin and Khatoon, 2013; Ahamlu et al., 2016). Absorption of AA occurs by both simple diffusion and active transport mechanisms that may be affected by means and routes of AA supplementation including feed, water or injection, among others (Savini et al., 2008).

Apparently, the performances of poultry in supplementation of AA as anti-heat stress under hot environmental temperatures through different means or routes need an investigation. Therefore, this study was designed to evaluate some productive and physiological performances of ready to lay pullets supplemented with AA through feed, water, and both feed and water.

\section{MATERIALS AND MethodS}

\subsection{Experimental Birds}

A total of eighty (80) 4-month old Bovan pullets of similar body weights were maintained at 24.3$37.7^{\circ} \mathrm{C}$ in a-14 light/10 darkness hour schedule during hot summer months (August - September) for six weeks. Feed and clean drinking water were provided ad-libitum.

\subsection{Experimental Design}

Birds were divided into four experimental treatments (A, B, C, and D) of four replicates each in a completely randomized block design .Each replicate was subdivided into five hens raised in an open management system using two layer battery cages. Basal diet, drinking water, and/ AA supplementation were provided to each treatment as designed in Table (1).

Table1. Experimental design of four treatments for Bovan pullets raised for six weeks

\begin{tabular}{|c|l|l|}
\hline Experimental Treatment & \multicolumn{2}{|c|}{ Basal diet, Drinking water, and/ AA supplementation } \\
\hline $\mathrm{A}$ & AA- free basal diet & AA- free drinking water \\
\hline $\mathrm{B}$ & $1,000 \mathrm{mg} \mathrm{AA} / \mathrm{kg}$ diet -basal diet & AA- free drinking water \\
\hline $\mathrm{C}$ & $500 \mathrm{mg} \mathrm{AA} / \mathrm{kg}$ diet- basal diet & $500 \mathrm{mg} \mathrm{AA} / \mathrm{kg}$ diet - drinking water \\
\hline $\mathrm{D}$ & AA- free basal diet & $1,000 \mathrm{mg} \mathrm{AA} / \mathrm{kg}$ diet - drinking water. \\
\hline
\end{tabular}

\subsection{Experimental Diet}

A layer basal diet was prepared as shown in Table (2) and fed to the birds.

Table2. Components and chemical composition of basal diet for experimental Bovan pullets

\begin{tabular}{|l|c|l|c|}
\hline Components & Quantity $(\mathrm{g} / \mathrm{kg})$ & Chemical composition & Percentage $(\%)$ \\
\hline Sorghum grains & 650.0 & Dry matter & 95.10 \\
\hline Wheat brand & 125.0 & Crude protein & 14.51 \\
\hline Groundnut cake & 090.0 & Ether extract & 04.41 \\
\hline Super concentrate & 050.0 & Crude fiber & 03.80 \\
\hline Marble dust & 080.0 & Ash & 13.50 \\
\hline Vitamin and mineral premix & 002.5 & Calcium & 03.42 \\
\hline Common salt & 002.5 & Phosphorus & 00.76 \\
\hline
\end{tabular}

\subsection{Feed Intake and Body Weight}

Feed intake and body weight were calculated as described by Ochi et al. (2015) and recorded initially and weekly for six weeks. FCR was calculated as follows:

FCR=Feed intake $(\mathrm{g} /$ bird $) \div$ Body weight $(\mathrm{g} /$ bird $)$

\subsection{Body Temperature $\left({ }^{\circ} \mathrm{C}\right)$}

Daily body temperature was measured at noon using a clinical thermometer on cloacal mucosa. 


\subsection{Total and Differential Leucocyte Counts}

Total and differential leucocyte counts were undertaken at the end of the experiment. Three birds were sacrificed randomly from each replicate and $2.0 \mathrm{ml}$ whole blood drawn from wing vein in a vacuotainer tube with anticoagulant. Blood samples for the TLC were diluted as described earlier by Natt and Herrick (1952). Counting was made using hemocytometer. Giemsa stained blood smears were prepared for differential leucocytic counts (Humason, 1972), emphasizing on heterophils and lymphocytes.

\subsection{Heterophils to Lymphocytes ( $H$ to $L)$ Ratio}

Heterophils to lymphocytes ( $\mathrm{H}$ to $\mathrm{L}$ ) ratio was calculated as follows:

$\mathrm{H}$ to $\mathrm{L}$ ratio $=$ Heterophils $/ 100$ cells $\div$ Lymphocytes $/ 100$ cells

\subsection{Statistical Analysis}

Data were managed and analyzed using analysis of variance (ANOVA).Separation of differences among the means was made using Duncan's Multiple Range Test. Significance difference was taken at $\mathrm{p}<0.05$ level.

\section{RESULTS AND DISCUSSION}

The effects of different methods in AA supplementation on the performances of pullets (Table 3) showed that the final body weight gain had a significant $(p<0.05)$ treatment increase. The mean body weight of the birds supplemented with AA in feed only (Treatment B) was significantly $10.10 \mathrm{~g}$ higher than AA - supplementation in both feed and water (Treatment C). The AA non-supplemented hens (Treatment A) significantly showed the least final body weight gain ( $828.4 \mathrm{~g} / \mathrm{bird})$ compared to all other treatments including birds supplemented with AA in water alone $(855.20 \mathrm{~g} / \mathrm{bird})$ in Treatment D. The improvement in the body weight gain of AA supplemented hens could be explained by the fact that AA supplementation enhances growth rate of the birds associated with reduction in body temperature (Oluyemi, 1979). This reflects the efficiency of AA as anti-heat stress, as such the best performance in body weight gain is associated with higher feed intake that induced by AA supplementation.

FCR showed a significant $(\mathrm{p}<0.05)$ negative effect of AA supplementation on feed utilization efficiency. It seems that there is no clear explanation to justify the poor FCR associated with AA supplemented birds. However, such a ratio might express indirectly the convert cost of maintaining birds under approximately normal physiological body status. Supplementation of $250 \mathrm{mg}$ of AA per $\mathrm{kg}$ of feed was found to be optimum to improve feed intake, body weight gain, feed efficiency, egg production and quality, nutrient digestibility, immune responses and antioxidant status in poultry birds (Khan et al., 2012).

The mean body temperature showed a significant $(\mathrm{p}<0.05)$ treatment decrease $\left(41.53^{\circ} \mathrm{C}\right)$ in the birds supplemented with AA in feed only compared to birds supplemented with AA in both feed and water $\left(41.56^{\circ} \mathrm{C}\right)$. Moreover, the latter experienced lower body temperature compared to birds supplemented with AA in water only $\left(41.59^{\circ} \mathrm{C}\right)$ or those exposed to the basal diet, which reflected the highest body temperature $\left(42.13{ }^{\circ} \mathrm{C}\right)$. Nevertheless, the birds supplemented with AA dissipated more heat and maintained significantly lower body temperature compared to the control group. It seemed that the ambient temperature ranged between $24.3-37.7^{\circ} \mathrm{C}$ during the study had caused insufficient synthesis and increased demand for AA by non-supplemented hens (Abidin and Khatoon, 2013 ; Ahamlu et al., 2016). However, Ait -Boulahsen et al. (1995) found that Potassium chloride could improve the thermotolerance of chickens exposed to acute heat stress. Supplementation of sodium bicarbonate in the poultry diet could improve eggshell quality at high temperatures (Balnave and Muheereza , 1997). On the contrary, Hayat et al. (1999) reported that Sodium bicarbonate and potassium bicarbonate supplements for broilers could cause poor performance at high temperatures. The disparity might be related to the different purposes of poultry production. 
Nevertheless, the significant reduction in body temperature of AA supplemented hens and the exceeding drop in temperature of the birds supplemented with AA in the basal diet compared to the rest of groups, suggesting that the absorption of the AA in the intestines and its utilization by the tissues differ based on the means of supplementation. Pardue et al. (1984) confirmed that with increased AA intake using water, the absorption and utilization of AA by chicken could be reduced due to excessive renal excretion of AA.

Total leucocytes count (TLC) among the birds supplemented with AA were more or less similar but significantly $(\mathrm{p}<0.05)$ higher compared to control group (Treatment A). The reduction in the TLC in control group seemed to be due to heat stress which could deplete the level of the indigenous AA (Gross et al., 1980). However, such a reduction in the TLC was previously documented as an important stress indicator (Wolford and Ringer, 1962). Heterophils to lymphocytes ratio showed no significant treatment effect despite that the $\mathrm{H}$ to $\mathrm{L}$ ratios of AA supplemented birds were lower $(0.344,0.349$, and 0.350$)$ compared to control group. The highest value $(0.353)$ of heterophils to lymphocytes ratio shown in control group could be a reliable indicator of heat stress as evaluated and confirmed by Gross and Siegel (1983) and Post et al. (2003).

Table3. Productive and physiological performances of Pullets influenced by supplementation of Ascorbic Acid

\begin{tabular}{|c|c|c|c|c|c|c|}
\hline \multirow[b]{2}{*}{ Parameters } & \multicolumn{4}{|c|}{ Treatments } & \multirow[b]{2}{*}{ Probability } & \multirow[b]{2}{*}{ SEM } \\
\hline & A & B & $\mathrm{C}$ & $\mathrm{D}$ & & \\
\hline Initial body weight (g/bird) & 783.60 & 780.20 & 779.70 & 779.60 & - & - \\
\hline Final body weight $(\mathrm{g} / \mathrm{bird})^{\mathrm{I}}$ & $828.40^{\mathrm{d}}$ & $872.10^{\mathrm{a}}$ & $862.00^{\mathrm{bc}}$ & $855.20^{\mathrm{c}}$ & $*$ & 7.240 \\
\hline Feed intake(g/bird) & 1656.80 & 1918.60 & 1896.40 & 1881.40 & - & - \\
\hline $\begin{array}{l}\text { Feed conversion ratio } \\
(\mathrm{g} \text { feed/g body wt./ bird })^{\mathrm{r}}\end{array}$ & $2.00^{\mathrm{a}}$ & $2.27^{\mathrm{d}}$ & $2.20^{\mathrm{bc}}$ & $2.22^{\mathrm{c}}$ & $*$ & 0.330 \\
\hline Body temperature $\left({ }^{\circ} \mathrm{C}\right)$ & $42.13^{\mathrm{d}}$ & $41.53^{\mathrm{ab}}$ & $41.56^{\mathrm{bc}}$ & $41.59^{\mathrm{c}}$ & $*$ & 0.025 \\
\hline $\begin{array}{l}\text { Total leukocyte count } \\
\left(1000 \text { cell/mm } / \mathrm{mm}^{3} \text { blood }\right)^{2}\end{array}$ & $23,000^{\mathrm{d}}$ & $28,000^{\mathrm{b}}$ & $28,033^{\mathrm{a}}$ & $27,833^{\mathrm{c}}$ & $*$ & 0.330 \\
\hline Heterophils /lymphocytes (Ratio) & 0.353 & 0.344 & 0.349 & 0.350 & NS & 0.013 \\
\hline
\end{tabular}

I- Values are means of four replicates of five birds each.

2. Values are means of four replicates of three birds each.

$a, b, c, d$-Means not sharing common superscript letters within a raw are significantly different at $5 \%$ level.

*-Significant difference $(p<0.05)$

NS- None significant

\section{SEM - Standard error of means}

\section{CONCLUSION}

Ascorbic acid supplementation had significant positive effect on the final body weight gain, body temperature and total leukocytes count. Feed conversion ratio and Heterophils to lymphocytes ratio showed no significant treatment effects. Ascorbic acid supplementation could be utilized to sustainably improve the productive and physiological performances of birds when exposed to optimum heat stress.

\section{ACKNOWLEDGEMENTS}

University of Bahri is sincerely indebted for encouraging academic research.

\section{REFERENCES}

[1] Abidin, Z. and Khatoon, A. (2013). Heat stress in poultry and the beneficial effects of ascorbic acid supplementation during heat stress. World's Poultry Science Journal, 69 (1): 135-152.

[2] Ahamlu, S., Mohammed, A. A., Bhan, H. and Auwal, A. (2016).An overview of Vitamin C as anti-stress in poultry. Malaysian J. Vet. Res., 7 (2): 9-22.

[3] Ait-Boulahsen, A., Garlich, J.D. and Edens, F.W. (1995). Potassium chloride improves the thermotolerance of chickens exposed to acute heat stress. Poultry Science, 74: 75-87.

[4] Ajakayie, J.J., Perez, J. J., Bello, A. and Mollineda, T.A. (2011). Impact of heat stress on egg quality in layer hens supplemented with L- Ascorbic acid and dl- tocopherol acetate. Veterinarian Archive, 81 (1):119-137. 
[5] Balnave, D. and Muheereza, S.K. (1997). Improving eggshell quality at high temperatures with dietary sodium bicarbonate. Poultry Science, 76: 588-593.

[6] Bashir, I. N., Munir , M.A., Saeed, M.A., Raz, A. and Raza, F.K. (1998). Immuno-modulatory effects of water soluble vitamins on heat stressed broiler chickens. Indian Journal of Animal Nutrition, 15: 11-17.

[7] Bollinger-Lee, S., Williams, P. E.V. and Whitehead, C. C. (1999). Optimal dietary concentration of vitamin $\mathrm{E}$ for alleviating the effect of heat stress on egg production in laying hens. British Poultry Science, 40:102-107.

[8] Ciftci, M., Ertas, O.N. and Guler, T. (2005). Effects of vitamin E and vitamin C dietary supplementation on egg production and egg quality of laying hens exposed to a chronic heat stress. Revue de Medecine Veterinaire, 156: 107-111.

[9] Gous, R.M. and Morris, T.R. (2005). Nutritional interventions in alleviating the effects of high temperatures in broiler production. World's Poultry Science, 61: 463-475.

[10] Gross, W. B., Sigel, P.B. and Dubose, R.T.(1980). Some effects of feeding corticosterone to chickens. Poultry Science, 59: 516-522.

[11] Gross, W.B. and Siegel, H.S. (1983). Evaluation of the heterophil/lymphocyte ratio as a measure of stress in chickens. Avian Diseases, 27: 972-979.

[12] Hayat, J., Balnave, D. and Brake, J. (1999). Sodium bicarbonate and potassium bicarbonate supplements for broilers can cause poor performance at high temperatures

[13] Humason, G. L. (1972). Animal tissue techniques, $3^{\text {rd }}$ edition. Freeman and Company, San Francisco, USA, pp 230.

[14] Jadhav, N. V., Awati, B., Kulkarris, S., Waghmare, P. G., Surangi, M. D., Saxena, M. J., Ravikanth, K., Dandale, M. and Shivimaini Maini (2013). Performance of layer birds supplemented with herbal antistress and synthetic vitamin C under physiological heat stress. Mal. J. Anim. Sci., 16 (1): 67-78.

[15] John, R. C. and John, F. L. (1975). The science of animal that serves mankind. Mc Grew Hill, New York, USA, pp 397.

[16] Khan, R.U., Naz, S., Nikousefat, Z. and Selvaggi, M. (2012). Effect of Ascorbic acid in heat-stressed poultry. World's Poultry Science Journal, 68 (3):477-490.

[17] Mack, L. A. (2013). Genetic variations alter production and behavioral responses during heat stress in two strains of laying hens. Poultry Science, 92: 285-294.

[18] Mashaly, M. M., Hendricks, G. L., Kalama , M. A., Gehad, A. E., Abbas, A. O. and Patterson, P. H. (2004). Effect of heat stress on production parameters and immune responses of commercial laying hens. Poultry Science, 83:889-894.

[19] Melvin, J. S. (1977). Dukes' Physiology of Domestic Animals, $9^{\text {th }}$ edition.Vail-Ballou Press, Cornell, USA, pp 391.

[20] Natt, M. R. and Herrick, C. A. (1952). A new blood diluent for counting the erythrocytes and leukocytes of the chicken. Poultry Science, 31: 735-738.

[21] North, M. O. and Bell, D. D. (1990). Commercial chicken production manual. Chapman and Hall, New York, USA, pp: 250-258.

[22] NRC (1994). National Research Council: National requirement of poultry, $9^{\text {th }}$ rev. edtion. Natt. Acad. Sci., Washington, DC., USA.

[23] Ochi, E. B., Elbushra, M.E., Fatur, M., Abubakr O. Ismail and Hafiz Abdalla (2015). Effect of Moringa (Moringa oleifera Lam) on the Performance and Carcass Characteristics of Broiler Chickens. Journal of Natural Sciences Research, 5(8): 66-73.

[24] Oluyemi, J. A.(1979). Measures applied to combat thermal stress in poultry under practical tropical environment. Poultry Science, 58: 767-773.

[25] Pardue, S. L., Thaxton, J. P. and Brake, J.(1984). Plasma ascorbic acid concentration following ascorbic acid loading in chicken. Poultry Science, 63: 2492-2496.

[26] Post, J., Rebel, J. M. J. and Hume, A. H. M. (2003). Automated blood cell count: Sensible and reliable method to study corticosterone- related stress in broilers. Poult. Sci., 82:591-595.

[27] Sahin, K., Sahin, N. and Yaralioglu, S. (2002). Effects of vitamin C and vitamin E on lipid peroxidation, blood serum metabolites, and mineral concentrations of laying hens reared at high ambient temperature. Biological Trace Element Research, 85: 35-45.

[28] Sahin, K., Sahin, N., Kucuk, O., Hayirli, A. and Prasad, A. S. (2009). Role of dietary Zinc in heat stressed poultry: A Review. Poultry Science, 88: 2176-2183. 
[29] Savini, I., Rossi, A., Pierro, C., Avigliano, L. and Catani, M. V. (2008). SVCT1 and SVCT2: Key proteins for vitamin $\mathrm{C}$ uptake on performance, digestibility, egg production and egg quality in laying hens under different environmental temperatures. Asian-Aust. J. Anim. Sci., 21(80): 1164-1170.

[30] Sigel, P. B. (1995). Effect of stress stimuli on health. In: Wenger R. M., (ed.), Proceeding of $2^{\text {nd }}$ European Symposium on Poultry. World Poultry Association, Celle, F R G, pp 36-39.

[31] Wolford, J. H. and Ringer, R. K. (1962). Adrenal weight, adrenal ascorbic acid, adrenal cholesterol and differential leukocyte as physiological indicators of stressor agents in laying hens. Poult. Sci., 41: 15211529 .

Citation: A.M. Abdalla \& Erneo B. Ochi, "Effect of Ascorbic Acid Supplementation Methods on Some Productive and Physiological Performances of Laying Hens", International Journal of Research Studies in Biosciences (IJRSB), vol. 6, no. 1, pp. 10-15, 2018. http://dx.doi.org/10.20431/2349-0365.0601003

Copyright: (C) 2018 Authors. This is an open-access article distributed under the terms of the Creative Commons Attribution License, which permits unrestricted use, distribution, and reproduction in any medium, provided the original author and source are credited. 